\title{
The Economic Impact of Indonesia-Bangladesh Preferential Trade Agreement
}

\author{
Devina Cieny Juventia \\ Trade Analysis of Policy and \\ Development Agency \\ Ministry of Trade \\ Jakarta, Indonesia \\ devinacieny@gmail.com
}

\author{
Eka Choirulina \\ Trade Analysis of Policy and \\ Development Agency \\ Ministry of trade \\ Jakarta, Indonesia \\ choirulinaeka@gmail.com
}

\author{
Yucky Anggun Anggrainy \\ Trade Analysis of Policy and \\ Development Agency \\ Ministry of Trade \\ Jakarta, Indonesia \\ yuckyanggun6695@gmail.com
}

\begin{abstract}
This study aims to review the economic impact of PTA and arrange indications of product requests/offers. The methods used are Revealed Comparative Advantage, Trade Complementary Index, and Partial Equilibrium. The study found that the TCI for Indonesia is $\mathbf{1 8 . 4}$ while Bangladesh is 3.31. Here, Indonesia can fulfill better the demand from Bangladesh. Based on RCA analysis, Indonesia has a better advantage on animal; vegetable; foodstuffs; mineral; plastic/rubber; and wood product. Meanwhile, Bangladesh has a better advantage on raw hides, skins, leather and furs; textile; and footwear/headgear. From Partial Equilibrium simulations show that the reciprocal decline in import tariffs between the two countries will increase Indonesia's export by USD 138.4 million, meanwhile Indonesia's import will increase by USD 94.7 million. Both countries will obtain welfare in the form of consumer surpluses, for Indonesia is USD 10.4 million and Bangladesh USD 8.2 million. Potential loss of Indonesia's revenue was due to a reduction in tariffs of USD 8.9 million and potential loss of Bangladesh's revenue of USD 66.5 million. We suggest for the initial stages of trade cooperation between Indonesia and Bangladesh to form the PTA with an indication of Indonesia's requests of 145 post tariffs and offers of 180 post tariffs.
\end{abstract}

\section{Keywords-Partial Equilibrium, PTA, Request/Offer}

\section{INTRODUCTION}

Bangladesh is a big market with a population of more than 164 million people and had an economic growth by $7.1 \%$ in 2017. This makes Bangladesh a very potential market to gain Indonesian market access to non-traditional countries. Bangladesh welcomed the bilateral cooperation plan at a meeting between the Indonesian Foreign Minister and the Bangladeshi Minister of Foreign Affairs in Dhaka in February 2019. The most appropriate form of cooperation for the start was the Preferential Trade Agreement (PTA). In the establishment of the PTA, Indonesia needs to discuss and analyze macroeconomic indicators, trade relations, tariff structures and the feasibility of cooperation. In addition, Indonesia must also arrange requests / offers that will be negotiated with the Indonesia-Bangladesh PTA. The purpose of this analysis is to analyze trade performance between Indonesia and Bangladesh and also calculate the benefits and costs from PTA between Indonesia and Bangladesh.

\section{METHODOLOGY}

This analysis uses quantitative and qualitative methods using secondary data. Secondary data obtained are then used to analyze trade data between Indonesia and Bangladesh both bilaterally and the performance of trade with the world.
This analysis uses trade indicators in bilateral and global trade agreements, major export and import products, competitiveness index Revealed Comparative Advantage and Trade Complementarity Index. This analysis calculates the impact (benefits and costs) of trade cooperation using Partial Equilibrium (PE) analysis.

\section{A. Revealed Comparative Advantage (RCA)}

One of the most widely used methods for measuring a country's trade weaknesses and advantages is Revealed Comparative Advantage (RCA). The RCA Balassa Index determines share a country's exports normalized by exports in the same industry or product in a group of countries. The RCA Balassa formula is formulated as follows:

$$
R C A=\left(\frac{X_{i j}^{k} / \sum_{k} X_{i j}^{k}}{X_{w j}^{k} / \sum_{k} X_{w j}^{k}}\right)
$$

Where $\mathrm{X}$ denotes export, $\mathrm{k}$ denotes the classification of commodities, $i$ denotes the exporting country, $j$ the country of export destination, and $\mathrm{w}$ denotes the world. It should be noted that partner countries $\mathrm{j}$ can provide other economic forms to calculate bilateral RCA or to calculate RCA in regional or global scope. The RCA value between 1 and the incomparable limit state that a product from i country has competitiveness in country $\mathrm{j}$. While the value of RCA is less than one to the zero limit recognizing that a product does not have competitiveness in country $\mathrm{j}$.

\section{B. Trade Complementary Index (TCI)}

The TCI index summarizes the level of trade complementarity of a country. This index shows whether two partner countries are complementary countries in trade or competing countries. The complementary trade index between the two countries is formulated as follows:

$$
T C I_{i j}=100-\sum_{k=1}^{n} \frac{\left|m_{k}^{k}-x_{i}^{k}\right|}{2}
$$

Where $x_{i}^{k}$ is the share of $i$ country exports for product $\mathrm{k}$ to the total exports. While $m_{j}^{k}$ is the share of $\mathrm{j}$ country imports for the same product $\mathrm{k}$ to the total imports $\mathrm{j}$ country. Thus $x_{i}^{k}$ and $m_{j}^{k}$ are formulated as follows: 


$$
x_{i}^{k}=\left(\frac{X_{i w}^{k}}{X_{i w}}\right)_{\text {and }} m_{j}^{k}=\left(\frac{M_{j w}^{k}}{M_{j w}}\right)
$$

TCI formula above shows the complementarity of country exports $\mathrm{i}$ to country $\mathrm{j}$. To measure import complementarity can use the formula as above by converting exporting countries to importers.

\section{Partial Equilibrium Model}

SMART Model or "Single Market Partial Equilibrium Simulation Tool" is a partial equilibrium model that can be used to calculate the tariff increase to the disaggregation of the HS 6 digits. This study discusses what is done by SMART and calculates a more detailed rate of reduction in disaggregation rates, which is agreed at the postal tariff level for each country.

Data and characteristics of partial equilibrium are based on the following provisions: First, the value of trade is treated as a quantity and world prices are considered one. Second, domestic prices are equal to world prices plus applicable rates. Third, there are three parameters used in this model, namely the import demand elasticity; export supply elasticity; and substitution elasticity.

\section{Trade Complementary Index (TCI)}

Indications requests and offers Indonesia with partner countries that are used weighing several indicators. In determining the Request List, a weighting method is used with 4 indicators used to determine the priority products, namely:

1) Tariffs with a weight of 0.3 ;

2) Imports of partner countries from Indonesia weighing 0.3 ;

3) Imports of partner countries from the world weighing 0.2 ;

4) Indonesia's exports to the world weigh 0.2 .

While to determine the potential of the Offers List, a weighting method is used. There are 4 indicators that are used to determine the priority products:

1) Tariffs with a weighing 0.3 ;

2) Indonesian imports from partner countries weighing 0.3 ;

3) Indonesian imports from the world weighing 0.2 ;

4) Export of partner countries to the world with a weight of 0.2 .

\section{RESULTS AND ANALYSIS}

\section{A. General Description of Bangladesh}

Based on macroeconomic indicators, Indonesia's economic growth is greater than Bangladesh (Table I). In 2018, Indonesia's GDP reached USD 1,022.45 billion while Bangladesh only amounted to USD 287.63 billion. With Indonesia's population 264.16 million, the income per capita of the Indonesian population reaches USD 3,870.56 per year. While Bangladesh has a population of 164.88 million, with a per capita income of USD 1,744.51 per year. Bangladesh's inflation is slightly higher at $5.56 \%$ compared to Indonesia which was $3.20 \%$.
TABLE I. COMPARISON OF MACROECONOMIC INDICATORS BETWEEN INDONESIA AND BANGLADESH

\begin{tabular}{|l|c|c|}
\hline \multicolumn{1}{|c|}{ Macroeconomic Indicators (2018) } & Indonesia & Bangladesh \\
\hline GDP, current price (USD Billion) & $1,022.45$ & 287.63 \\
\hline GDP per capita (USD) & $3,870.56$ & $1,744.51$ \\
\hline Inflation, average consumer price (\%) & 3.20 & 5.56 \\
\hline \multicolumn{2}{|r|}{ Population (Million) Source: IMF, 2019 (processed by the BPPP, Ministry of Trade) }
\end{tabular}

\section{B. Trade Performance of Indonesia-Bangladesh}

\section{1) Indonesia-Bangladesh Trade Balance}

Trade performance total Indonesia-Bangladesh's over the past five years has continued to increase by an average of $8.3 \%$ per year. In terms of Indonesia's exports performance to Bangladesh, there was an increasing trend by an average of $8.4 \%$ per year during the $2014-2018$ period.

Meanwhile in terms of imports, in the last 5 years, Indonesia's imports from Bangladesh increase by an average of $6.8 \%$ per year. Indonesia's imports from Bangladesh are only in the non-oil and gas sector. Thus, Indonesia's trade balance with Bangladesh managed to record a trade surplus for Indonesia with an average increase of $8.5 \%$ per year during 2014-2018 (Table II).

TABLE II. TRADE BALANCE BETWEEN INDONESIA AND BANGLADESH

\begin{tabular}{|c|c|c|c|c|c|c|c|}
\hline \multirow{2}{*}{ Description } & \multicolumn{5}{|c|}{ Value : USD Million } & \multirow{2}{*}{$\begin{array}{c}\begin{array}{c}\text { Growth } \\
(\%)\end{array} \\
2018 / 17\end{array}$} & \multirow{2}{*}{$\begin{array}{c}\begin{array}{c}\text { Trend } \\
(\%)\end{array} \\
2014-18\end{array}$} \\
\hline & 2014 & 2015 & 2016 & 2017 & 2018 & & \\
\hline TRADE TO TAL & $1,448.9$ & $1,400.3$ & $1,335.1$ & $1,668.9$ & $1,977.5$ & 18.5 & 8.3 \\
\hline Oil \& Gas & 2.3 & 0.2 & 0.7 & 16.1 & 150.5 & 833.1 & 251.6 \\
\hline Non Oil \& Gas & $1,446.6$ & $1,400.0$ & $1,334.4$ & $\begin{array}{ll}1,652.8 \\
\end{array}$ & $1,827.0$ & 10.5 & 6.5 \\
\hline EKSPORT & $1,377.6$ & $1,340.8$ & $1,266.7$ & $1,595.7$ & $1,888.0$ & 18.3 & 8.4 \\
\hline Oil \& Gas & 2.3 & 0.2 & 0.7 & 16.1 & 150.5 & 833.1 & 251.6 \\
\hline Non Oil \& Gas & $1,375.3$ & $1,340.6$ & $1,266.0$ & \begin{tabular}{l|l|}
$1,579.6$ \\
\end{tabular} & $1,737.6$ & 10.0 & 6.5 \\
\hline IMPORT & 71.3 & 59.5 & 68.4 & 73.1 & 89.5 & 22.3 & 6.8 \\
\hline Oil \& Gas & & & & & & & \\
\hline Non Oil \& Gas & 71.3 & 59.5 & 68.4 & 73.1 & 89.5 & 22.3 & 6.8 \\
\hline TRADE BALANCE & $1,306.3$ & $1,281.3$ & $1,198.3$ & $1,522.6$ & $1,798.6$ & 18.1 & 8.5 \\
\hline Oil \& Gas & 2.3 & 0.2 & 0.7 & 16.1 & 150.5 & 833.1 & 251.6 \\
\hline Non Oil \& Gas & $1,304.0$ & $1,281.1$ & $\begin{array}{ll}1,197.6 \\
\end{array}$ & \begin{tabular}{l|l}
$1,506.5$ \\
\end{tabular} & $1,648.1$ & \begin{tabular}{l|l}
9.4 \\
\end{tabular} & 6.5 \\
\hline
\end{tabular}

In 2018, Bangladesh is Indonesia's 19th export destination country with an export value of USD 1.89 billion. The share value of Indonesia's exports to Bangladesh reaches $1.05 \%$ of Indonesia's total exports to the world. Indonesia's main export products to Bangladesh are dominated by palm oil and its derivatives by discussing the market at $44.49 \%$. Other major export products are pulpwood, refined petroleum, and coal.

TABLE III. INDONESIA'S MAIN EXPORT PRODUCTS TO BANGLADESH

\begin{tabular}{|c|c|c|c|c|}
\hline \multirow[t]{2}{*}{ No } & \multirow[t]{2}{*}{ HS Code } & \multirow[t]{2}{*}{ Description } & \multirow{2}{*}{$\begin{array}{c}\begin{array}{c}\text { Value : USD } \\
000\end{array} \\
2018\end{array}$} & \multirow{2}{*}{$\begin{array}{c}\text { Share }(\%) \\
2018 \\
\end{array}$} \\
\hline & & & & \\
\hline \multicolumn{3}{|r|}{ Total } & $1,888,032$ & 100.0 \\
\hline 1 & '151190 & Palm oil and its fractions, whether & 840,068 & 44.5 \\
\hline 2 & '470329 & Semi-bleached or bleached non-cc & 149,725 & 7.9 \\
\hline 3 & '271019 & Medium oils and preparations, of $\mathrm{A}$ & 149,139 & 7.9 \\
\hline 4 & 270119 & Coal, whether or not pulverised, ne & 144,779 & 7.7 \\
\hline 5 & '252310 & Cement clinkers & 63,997 & 3.4 \\
\hline 6 & '550320 & Staple fibres of polyesters, not car & 43,860 & 2.3 \\
\hline 7 & '550410 & Staple fibres of viscose rayon, not & 29,425 & 1.6 \\
\hline 8 & '390769 & Poly"ethylene terephthalate", in $\mathrm{p}$ & 28,821 & 1.5 \\
\hline 9 & '960720 & Parts of slide fasteners & 19,885 & 1.1 \\
\hline 10 & 120300 & Copra & 18,387 & 1.0 \\
\hline \multicolumn{3}{|r|}{ Sub Total } & $1,488,086$ & 78.8 \\
\hline \multicolumn{3}{|r|}{ Others } & 399,946 & 21.2 \\
\hline
\end{tabular}


In 2018 Bangladesh places the $67^{\text {th }}$ rank in the country of origin of Indonesian imports with a total import value of USD 89.5 million. Textile products are Indonesia's main import products from Bangladesh.

\section{TABLE IV. INDONESIA'S MAIN IMPORT PRODUCTS FROM} BANGLADESH

\begin{tabular}{|c|c|c|c|c|}
\hline \multirow[t]{2}{*}{ No } & \multirow[t]{2}{*}{ HS Code } & \multirow[t]{2}{*}{ Description } & $\begin{array}{l}\text { Value : } \\
\text { USD } 000\end{array}$ & Share(\%) \\
\hline & & & 2018 & 2018 \\
\hline & & Total & 89,450 & 100.00 \\
\hline 1 & '530720 & Multiple "folded" or cabled yarn c & 20,832 & 23.29 \\
\hline 2 & '610910 & T-shirts, singlets and other vests $\mathrm{C}$ & 13,029 & 14.57 \\
\hline 3 & '620342 & Men's or boys' trousers, bib and b & 6,586 & 7.36 \\
\hline 4 & '620462 & Women's or girls' trousers, bib an & 5,401 & 6.04 \\
\hline 5 & '630510 & Sacks and bags, for the packing of & 4,501 & 5.03 \\
\hline 6 & '620520 & Men's or boys' shirts of cotton (ex & 2,687 & 3.00 \\
\hline 7 & '611120 & Babies' garments and clothing acc & 2,368 & 2.65 \\
\hline 8 & '611020 & Jerseys, pullovers, cardigans, wais & 2,130 & 2.38 \\
\hline 9 & '610990 & T-shirts, singlets and other vests $\mathrm{d}$ & 1,828 & 2.04 \\
\hline \multirow[t]{3}{*}{10} & '611030 & Jerseys, pullovers, cardigans, wais & 1,810 & 2.02 \\
\hline & & Sub Total & 61,172 & 68.39 \\
\hline & & Others & 28,278 & 31.61 \\
\hline
\end{tabular}

\section{2) Bangladesh Trade Performance with the World}

Bangladesh's main export products to the world are textile products. The total value of Bangladesh's exports in 2018 was USD 42.5 million. While Bangladesh imports are dominated by oil and gas products, cotton and palm oil products. The total value of Bangladesh imports is USD 53.4 million in 2018.

\section{Cooperation Feasibility Analysis}

\section{1) The Trade Complementarity Index / TCI}

Trade Complementarity Index (TCI) between Indonesia and Bangladesh is generally presented in Figure 1.

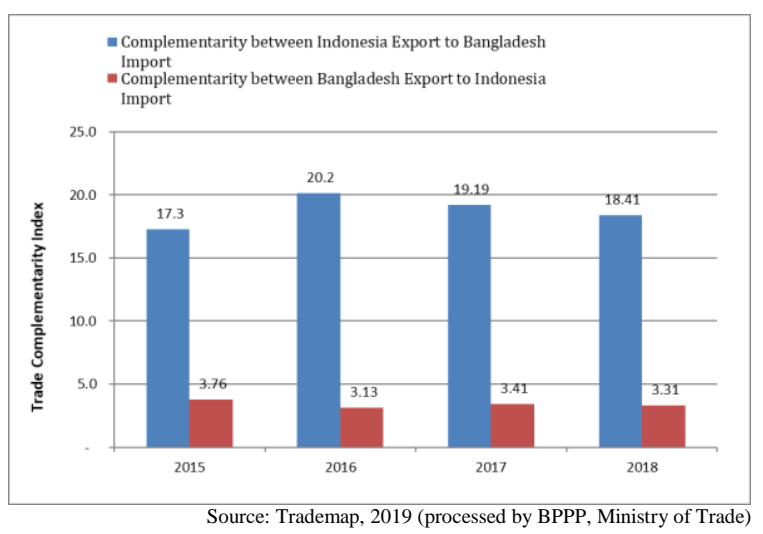

Fig. 1. TCI Indonesia-Bangladesh

Based on Figure 1, it can be seen that in 2018 level complementary Indonesia is 18.41 while Bangladesh is 3.31 . This means that Indonesia is better able to fulfil the demand for Bangladesh imports comparing Bangladesh to fulfil Indonesia's imports.

\section{2) Competitiveness Index / Revealed Symmetric Comparative Advantage (RSCA)}

Based on Revealed Symmetric Comparative Advantage (RSCA) obtained Indonesian products that have competitiveness in the expected global markets are animal and animal products; vegetable products; foodstuffs; mineral products; plastic/rubber; wood and wooden products; textile; and footwear/headgear. While Bangladesh products that have competitiveness in the global market are raw hides, skins, leather and furs; textile; and footwear/headgear.

Indonesia has a better advantage than Bangladesh in animal products; vegetable products; foodstuffs; mineral products; plastic/rubber; wood and wooden products. Meanwhile, Bangladesh has a better comparative advantage than Indonesia, namely the products of raw hides, skins, leather and furs; textile; and footwear/headgear (Table V).

\begin{tabular}{|c|c|c|c|c|}
\hline \multirow{2}{*}{ Sector } & \multicolumn{2}{|c|}{ RSCA Indonesia Relative to } & \multicolumn{2}{|c|}{ RSCA Bangladesh Relative to } \\
\hline & Bangladesh & Global & Indonesia & Global \\
\hline $\begin{array}{l}\text { animal and animal } \\
\text { product }\end{array}$ & 0.25 & 0.08 & -0.25 & -0.17 \\
\hline vegetable products & 0.97 & 0.62 & -0.97 & -0.87 \\
\hline foodstuffs & 0.79 & 0.13 & -0.79 & -0.74 \\
\hline mineral products & 0.99 & 0.30 & -0.99 & -0.99 \\
\hline $\begin{array}{l}\text { chemical and allied } \\
\text { industries }\end{array}$ & 0.93 & -0.14 & -0.93 & -0.95 \\
\hline plastics/rubber & 0.90 & 0.06 & -0.90 & -0.89 \\
\hline $\begin{array}{l}\text { raw hides, skins, } \\
\text { leather and furs }\end{array}$ & -0.48 & -0.23 & 0.48 & 0.29 \\
\hline $\begin{array}{l}\text { wood and wooden } \\
\text { products }\end{array}$ & 0.96 & 0.50 & -0.96 & -0.87 \\
\hline textile & -0.85 & 0.26 & 0.85 & 0.91 \\
\hline footwear/headgear & -0.01 & 0.55 & 0.01 & 0.55 \\
\hline stone/glass & 0.92 & -0.06 & -0.92 & -0.93 \\
\hline metals & 0.92 & -0.30 & -0.92 & -0.95 \\
\hline machinery/electrical & 0.94 & -0.50 & -0.94 & -0.98 \\
\hline transportation & 0.80 & -0.46 & -0.80 & -0.92 \\
\hline miscellaneous & 0.51 & -0.53 & -0.51 & -0.82 \\
\hline \multicolumn{5}{|c|}{ Explanatory Note } \\
\hline $\begin{array}{l}\text { Maximum Value of } \\
\text { RSCA }\end{array}$ & 1.00 & & & \\
\hline $\begin{array}{l}\text { Minimum Value of } \\
\text { RSCA }\end{array}$ & -1.00 & & & \\
\hline Critical Point & Comparative Adv & age $=>0$ & & \\
\hline
\end{tabular}

Source: Trademap, 2019 (processed by BPPP, Ministry of Trade)

\section{3) The Impact of Indonesia-Bangladesh Liberalization of Trade}

The potential impact of trade partnerships between Indonesia and Bangladesh is calculated by partial equilibrium with the scenario of reducing Bangladesh tariffs for products produced from Indonesia and vice versa. The simulation scenario is cutting rates up to $0 \%$ of all products. The simulation results are as follows.

TABLE VI. PARTIAL EQUILIBRIUM OF THE IMPACT OF TRADE COOPERATION INDONESIAN-BANGLADESH (USD THOUSAND)

\begin{tabular}{|l|r|r|r|}
\hline Importer & $\begin{array}{c}\text { Increasing } \\
\text { Impor }\end{array}$ & Welfare & $\begin{array}{c}\text { Loss Tarif } \\
\text { Revenue }\end{array}$ \\
\hline Indonesia & 94,715 & 10,427 & 8,869 \\
\hline Bangladesh & 138,447 & 8,196 & 66,492 \\
\hline
\end{tabular}

Based on the simulation results, it is seen that an increase of Indonesian export to Bangladesh amounted to USD 138.4 Million, while Bangladesh will increase export to Indonesia by USD 94.7 Million. Thus, tariff cuts from the two countries will increase Indonesia's trade balance. With the tariff cuts, each country will get a surplus on welfare, each of Indonesia amounting to USD 10.4 million and Bangladesh USD 8.2 million. In addition, tariff cuts were also effected on 
tariff lost revenue amounting to USD 8.8 million for Indonesia and USD 66.5 million for Bangladesh.

4) Bangladesh Products That Potentially as Indonesian Request

This analysis sets out indications of products priority for tariff reduction arrangements in Bangladesh or Request List. The weighted products are Indonesian products that have relatively greater competitiveness than Bangladesh (RSCA Indonesia relative to Bangladesh).

The range of Most Favored Nation (MFN) rates is between $0 \%$ and $25 \%$. Tariff $0 \%$ are only charged for 180 products or $3.5 \%$ of all Bangladesh products while very high rates $(25 \%)$ comprise 2,049 products or $39.4 \%$ of all products in 6 digits. Bangladesh also applies mixed tariffs (ad valorem tariff + specific tariffs for 23 products, including cement, sugar, aluminum and vehicles). Indonesian products, mostly require import duties between $10 \%-20 \%$, which is about $51 \%$ of Bangladesh's total imports from Indonesia. Only $6.8 \%$ of Indonesian products in Bangladesh's market have received a $0 \%$ import duty.

TABLE VII. BANGLADESH'S TARIFF STRUCTURE AND TRADE WITH INDONESIA

\begin{tabular}{c|cccc}
\hline $\begin{array}{c}\text { Tariff } \\
\text { Classification }\end{array}$ & $\begin{array}{c}\text { Tariff } \\
\text { Posts }\end{array}$ & $\begin{array}{c}\text { \% } \\
\text { Product }\end{array}$ & $\begin{array}{c}\text { Bangladesh's } \\
\text { Imports from } \\
\text { Indonesia } \\
\text { (USD 000) }\end{array}$ & $\begin{array}{c}\text { \% } \\
\text { Import }\end{array}$ \\
\hline $0 \%$ & 180 & 3.5 & 91,156 & 6.8 \\
\hline $0 \%<\mathrm{X} \leq 5 \%$ & 1,439 & 27.6 & 292,488 & 21.8 \\
\hline $5 \%<\mathrm{X} \leq 10 \%$ & 1,315 & 25.3 & 133,657 & 10.0 \\
\hline $10 \%<\mathrm{X} \leq 20 \%$ & 199 & 3.8 & 690,475 & 51.5 \\
\hline$>20 \%$ & 2,049 & 39.4 & 132,271 & 9.9 \\
\hline Specific Tariffs & 23 & 0.4 & 742 & 0.1 \\
\hline Total & $\mathbf{5 . 2 0 5}$ & $\mathbf{1 0 0}$ & $\mathbf{1 , 3 4 0 , 7 8 9}$ & $\mathbf{1 0 0}$ \\
\hline \multicolumn{7}{r}{ Source: WTO and Trademap, 2019 (processed by the Ministry of Trade's BPP) }
\end{tabular}

From the methods presented, 145 postal items were submitted to request list by Indonesia with the value of Bangladesh's imports from Indonesia amounting to USD 791 million. Based on the tariff rate, the request list consists of $10 \%-20 \%$ import duty of 2 tariff posts and more than $20 \%$ import duty of 143 tariff posts. The sector experiencing a decrease in tariffs in Bangladesh is vegetable products 13 tariff posts; textiles 61 tariff posts; wood products 21 postal; plastic/rubbers 17 tariff posts; foodstuffs 12 tariff posts; stone/glass 9 tariff posts; miscellaneous 8 tariff posts; mineral products 2 tariff posts; raw hides and skin 1 tariff post; animal products 1 tariff post.

TABLE VIII. REQUEST LIST PRODUCT SECTOR TO BANGLADESH

\begin{tabular}{|c|c|c|c|c|}
\hline Sector & $\begin{array}{l}\text { Bangladesh's } \\
\text { Imports from } \\
\text { Indonesia } \\
\text { (USD 000) }\end{array}$ & $\begin{array}{c}10 \%<X \\
<=20 \%\end{array}$ & $X>20 \%$ & $\begin{array}{c}\text { Sub } \\
\text { Total }\end{array}$ \\
\hline $\begin{array}{l}\text { Vegetable } \\
\text { products }\end{array}$ & 705,737 & 1 & 12 & 13 \\
\hline Textiles & 38,918 & - & 61 & 61 \\
\hline $\begin{array}{l}\text { Wood and } \\
\text { wooden products }\end{array}$ & 36,213 & - & 21 & 21 \\
\hline Plastics/rubber & 6,975 & - & 17 & 17 \\
\hline Foodstuffs & 1,411 & - & 12 & 12 \\
\hline Stone/glass & 987 & - & 9 & 9 \\
\hline Miscellaneous & 749 & - & 8 & 8 \\
\hline Mineral products & 230 & 1 & 1 & 2 \\
\hline Raw hides, skins, & 92 & - & 1 & 1 \\
\hline
\end{tabular}

\begin{tabular}{|c|c|c|c|c|}
\hline Sector & $\begin{array}{l}\text { Bangladesh's } \\
\text { Imports from } \\
\text { Indonesia } \\
\text { (USD 000) }\end{array}$ & $\begin{array}{c}10 \%<X \\
<=20 \%\end{array}$ & $X>20 \%$ & $\begin{array}{l}\text { Sub } \\
\text { Total }\end{array}$ \\
\hline \multicolumn{5}{|l|}{ leather \& furs } \\
\hline $\begin{array}{l}\text { Animal \& animal } \\
\text { products }\end{array}$ & 25 & - & 1 & 1 \\
\hline Total & 791,337 & 2 & 143 & 145 \\
\hline
\end{tabular}

\section{5) Potential Indonesian Products as an Offers List}

This analysis forms an indication of Indonesian products that can be a priority in reducing import tariffs from Bangladesh or indicating an Offer List. The weighted products are Bangladesh products that have relatively greater competitiveness compared to Indonesia (RSCA Bangladesh relative to Indonesia). Indonesian imports from Bangladesh in 2015 reached USD 41 million. As much as $63.4 \%$ of Indonesia's imports from Bangladesh are subject to a $5 \%$ import duty while $2.8 \%$ is received $0 \%$ import duty.

TABLE IX. TRADE AND RATES INDONESIAN WITH BANGLADESH

\begin{tabular}{ccccc}
\hline $\begin{array}{c}\text { Tariff } \\
\text { Classification }\end{array}$ & $\begin{array}{c}\text { Tariff } \\
\text { Posts }\end{array}$ & $\begin{array}{c}\% \\
\text { Product }\end{array}$ & $\begin{array}{c}\text { Indonesia's } \\
\text { Imports from } \\
\text { Bangladesh } \\
\text { (USD 000) }\end{array}$ & $\begin{array}{c}\% \\
\text { Import }\end{array}$ \\
\hline $0 \%$ & 1,250 & 12.5 & 2,053 & 3.5 \\
\hline $0 \%<\mathrm{X} \leq 5 \%$ & 5,383 & 53.8 & 24,921 & 41.9 \\
\hline $5 \%<\mathrm{X} \leq 10 \%$ & 1,880 & 18.8 & 686 & 1.2 \\
\hline $10 \%<\mathrm{X} \leq 20 \%$ & 1,206 & 12.0 & 31,679 & 53.3 \\
\hline$>20 \%$ & 228 & 2.3 & 131 & 0.2 \\
\hline $\begin{array}{c}\text { Others } \\
\text { (specific tariffs) }\end{array}$ & 65 & 0.6 & 0 & - \\
\hline Total & $\mathbf{1 0 . 0 1 2}$ & $\mathbf{1 0 0 , 0}$ & $\mathbf{5 9 . 4 7 0}$ & $\mathbf{1 0 0}$ \\
\hline & Source: WTO and Trademap, 2019 (processed by BPPP, Ministry of Trade)
\end{tabular}

From the methods that have been submitted, there are 180 products that indicate as Indonesia's offer list for Bangladesh with a trade value of USD 26.6 million. This offer list has been considered that there are no products that are head to head at the 6-digit HS level. Based on the tariff rate, Indonesia offer list indication structure consists of import duty rates of less than or equal to $5 \%$ of 107 tariff posts; $5 \%-10 \%$ import duty as many as 51 tariff posts; $10 \%$ $20 \%$ import duty of the 18 postal rates and the import duty is greater than $20 \%$ of the 4 tariff posts. The sector that receives a reduction in tariffs for Bangladesh is textile 32 post tariffs; chemicals \& allied industries related 7 post tariffs; metals 34 post tariffs; footwear/headgear 8 post tariffs; raw hides and skin 8 post tariffs; miscellaneous 10 tariff posts; machinery/electrical 58 post tariffs; wood products 8 post tariffs; plastics/rubbers 6 post tariffs; foodstuffs 5 post tariffs; animal products 1 tariff post; mineral products 2 post rates; and transportation 1 post tariff. 
TABLE X. PRODUCT SECTOR OFFER LIST TO BANGLADESH

\begin{tabular}{|l|c|c|c|c|c|c|}
\hline \multicolumn{1}{|c|}{ Sector } & $\begin{array}{c}\text { Indonesia's } \\
\text { Imports } \\
\text { from } \\
\text { Bangladesh } \\
\text { (USD 000) }\end{array}$ & $\begin{array}{c}\mathbf{0 \%} \\
<\mathbf{X} \\
<= \\
\mathbf{5 \%}\end{array}$ & $\begin{array}{c}\mathbf{5 \%} \\
<\mathbf{X} \\
<= \\
\mathbf{1 0 \%}\end{array}$ & $\begin{array}{c}\mathbf{1 0 \%} \\
<\mathbf{X} \\
<=\end{array}$ & $\begin{array}{c}\mathbf{X}> \\
\mathbf{2 0 \%}\end{array}$ & $\begin{array}{c}\text { Sub } \\
\text { Total }\end{array}$ \\
\hline Textiles & 21,211 & 14 & 9 & 9 & - & 32 \\
\hline $\begin{array}{l}\text { Chemicals \& } \\
\text { Allied } \\
\text { Industries }\end{array}$ & 2,251 & 7 & - & - & - & 7 \\
\hline Metals & 990 & 3 & 29 & 2 & - & 34 \\
\hline $\begin{array}{l}\text { Footwear/ } \\
\text { Headgear }\end{array}$ & 795 & - & 1 & 3 & 4 & 8 \\
\hline $\begin{array}{l}\text { Raw hides, } \\
\text { skins, leather } \\
\text { \& furs }\end{array}$ & 392 & 1 & 3 & 4 & - & 8 \\
\hline Miscellaneous & 383 & 9 & 1 & - & - & 10 \\
\hline $\begin{array}{l}\text { Machinery/ } \\
\text { electrical }\end{array}$ & 244 & 51 & 7 & - & - & 58 \\
\hline $\begin{array}{l}\text { Wood and } \\
\text { wooden } \\
\text { products }\end{array}$ & 128 & 8 & - & - & - & 8 \\
\hline $\begin{array}{l}\text { Plastics/ } \\
\text { rubber }\end{array}$ & 123 & 6 & - & - & - & 6 \\
\hline Foodstuffs & 27 & 5 & - & - & - & 5 \\
\hline $\begin{array}{l}\text { Animal \& } \\
\text { animal } \\
\text { products }\end{array}$ & 18 & 1 & - & - & - & 1 \\
\hline $\begin{array}{l}\text { Mineral } \\
\text { products }\end{array}$ & 7 & 2 & - & - & - & 2 \\
\hline Transportation & 3 & - & 1 & - & - & 1 \\
\hline Total & $\mathbf{2 6 , 5 7 2}$ & $\mathbf{1 0 7}$ & $\mathbf{5 1}$ & $\mathbf{1 8}$ & $\mathbf{4}$ & $\mathbf{1 8 0}$ \\
\hline & Source: Trademap, 2019 (processed by BPPP, Ministry of Trade) \\
\hline
\end{tabular}

\section{CONCLUSIONS AND RECOMMENDATIONS}

Indonesia's trade surplus with Bangladesh increases the average value of $8.5 \%$ per year during $2014-2018$ period. In 2018 the surplus amounted to USD 1.8 billion. Total exports in 2018 amounted to USD 1.89 billion and imports amounted to USD 89.5 million.

Indonesia's level complementary trade is 18.41 , higher than Bangladesh which is 3.31. Indonesia has a better advantage than Bangladesh in animal and animal products; vegetable products; foodstuffs; mineral products; plastic/rubber; wood and wooden products. Meanwhile, Bangladesh has a comparative advantage better than Indonesia, namely the products of raw hides, skins, leather and furs; textile; and footwear/headgear.

Based on the simulation of Partial Equilibrium, to show the benefits and costs of PTA between Indonesia and Bangladesh, it can be seen that Indonesia will be able to increase exports by USD 138.4 million, while Bangladesh will be able to increase exports by USD 94.7 million. Tariff cuts were also effected on tariff lost revenue amounting to USD 8.8 Million for Indonesia and USD 66.5 Million for Bangladesh. Thus, tariff cuts from the two countries will increase Indonesia's trade placement. By reducing import costs, the two countries will receive welfare of USD 10,4 million for Indonesia and USD 8.2 million for Bangladesh.

For the initial stage, trade cooperation between Indonesia and Bangladesh proposed in the form of a Preferential Trade Agreement (PTA) with the indications of request and offer is as follows:

\section{1) Indication of Indonesia's Requests}

a) 145 tariff posts indicating request list Indonesian with Bangladesh import value from Indonesia amounting to USD 791 million.

b) Based on the tariff rate, the order request list of $10 \%$ $20 \%$ import duty of 2 tariff posts and more than $20 \%$ import duties of 143 tariff posts.

c) The sector experiencing a decrease in tariffs in Bangladesh is vegetable products 13 tariff posts; textiles 61 tariff posts; wood products 21 tariff posts; plastic and rubber 17 tariff posts; foodstuffs 12 tariff posts; stone / glass 9 tariff posts, miscellaneous 8 tariff posts; mineral products 2 tariff posts, raw hides and skin 1 tariff post; animal products 1 tariff post.

\section{2) Indication of Indonesia's Offers}

a) 180 post tariffs indicative of products which offer list Indonesia for Bangladesh with a trade value of USD 26.6 million.

b) Based on the tariff rate, the list of Indonesian compositions consists of import duty rates of less than or equal to $5 \%$ of 107 tariff posts; $5 \%-10 \%$ import duty as many as 51 tariff posts; the import duty rate is between $10 \%-20 \%$ of the 18 postal rates and the import duty is greater than $20 \%$ of the 4 tariff posts.

c) The sector that receives a reduction in tariffs for Bangladesh is textile 32 post tariffs; chemical industry $\&$ industry related 7 post tariffs; metals 34 post tariffs; footwear 8 post tariffs; raw hides and skins 8 post tariffs; miscellaneous 10 tariff posts; machinery and electricity 58 post tariffs; wood products 8 post tariffs; plastic/rubbers 6 post tariffs; foodstuff 5 post tariffs; animal products 1 post tariff; mineral product 2 post tariffs; and transportation 1 post tariff.

\section{ACKNOWLEDGMENT}

The authors would like to thank to all fellows involved especially Mr. Deky Paryadi, Mr. Boris Situmorang, Mr. Muhammad Fawaiq, and Mr. Wibowo Kurniawan for giving their best contribution in this research.

\section{REFERENCES}

[1] R. Garnautt and P. Drysdale, "Asia Pacific Regionalism: Readings in International Economic Relations," Harper Education Publishers, Sydney, 1994.

[2] R. Oktaviani, E.I.K. Puteri, S. Hartoyo, Widyastutik, A. Rifin, dan E. Puspitawati, "Perhitungan Penerimaan Bea Masuk Berdasarkan Kebijakan tarif dalam Skema Umum dan Skema Free Trade Area dan Evaluasi Dampak Kebijakan Tarif Bea Masuk dalam Skema ASEANChina Free Trade Area dan ASEAN-Korea terhadap Pendapatan Negara," Departemen Keuangan, Jakarta, 2007.

[3] Hertel, "Global Trade Analysis, Modeling and Applications," Cambridge University Press, New York, 1997.

[4] M. Kotabe dan K. Helsen, "Global Marketing Management Second Edition," John Wiley and Sons Inc, New York, 2001.

[5] P. Krugman, "Increasing Returns and Economic Geography," Journal of Political Economy, University of Chicago Press, vol. 99 (3), pages 483-99, June 1991

[6] Krugman dan Obstfeld, "International Economics Theory and Policy," An imprint of Addison Wesley Longman, Inc, Massachosetts, 2000.

[7] M. P. Todaro dan S.C. Smith, "Pembangunan Ekonomi di Dunia Ketiga," Erlangga, Jakarta, 2003 